\title{
PERTANGGUNGJAWABAN PIDANA PELAKU TINDAK PIDANA PENIPUAN ONLINE DALAM HUKUM POSITIF DI INDONESIA
}

\author{
Oleh : \\ Ikka Puspitasari \\ Fakultas Hukum Universitas Diponegoro, \\ ikkapuspitasari@gmail.com
}

\begin{abstract}
ABSTRAK
Perkembangan teknologi informasi yang sangat pesat telah mempengaruhi seluruh aspek kehidupan termasuk aspek hukum yang berlaku. Kemajuan teknologi informasi tersebut antara lain ditandai dengan maraknya penggunaan media elektronik mulai dari penggunaan handphone hingga komputer yang semakin canggih. Internet yang berkembang demikian pesat sebagai kultur masyarakat modern, karena melalui internet berbagai aktivitas di dunia maya seperti berpikir, berkreasi, dan bertindak dapat diekspresikan didalamnya, kapanpun dan dimanapun. Tidak dapat dipungkiri bahwa kemajuan teknologi dan pengetahuan ini juga berdampak pada berkembangnya tindak kejahatan. Pelaku kejahatan tidak mengenal tempat atau dengan cara apapun selama bisa dijadikan tempat melakukan kejahatan. Kejahatan yang terjadi di dalam Internet dikenal dengan istilah Cyber Crime (kejahatan dalam dunia maya).
\end{abstract}

Kata kunci: Tehnologi, Tindak Pidana, Elektronik, Cyber Crime

\begin{abstract}
The development of rapid information technology has affected all aspects of life including law aspects. Information technology advances, among others, is marked by the rampant use of electronic media ranging from the use of mobile phones to increasingly sophisticated computer. The Internet is growing so rapidly as modern society culture, because through various internet activity on cyber as thinking, creating, and act can be expressed therein, whenever and wherever. It is undeniable that techonology and knowledge also have an impact on the rise of crime. The perpetrator of any crime does not know the place or in any way as long as it can be used as a place of crime. Crimes that occur in the Internet known as Cyber Crime (crime in cyberspace).
\end{abstract}

Keywords: Technology, Crime, Electronic, Cyber Crime 


\section{A. PENDAHULUAN}

\section{Latar Belakang}

Pengaruh globalisasi ${ }^{1}$ dengan penggunaan sarana teknologi informasi dan komunikasi telah mengubah pola hidup masyarakat, dan berkembang dalam tatanan kehidupan baru dan mendorong terjadinya perubahan sosial, ekonomi, budaya, pertahanan, keamanan, dan penegakan hukum. Dalam penggunaan sarana teknologi informasi dan komunikasi telah terjadi banyak penyimpangan yang merugikan banyak pihak. Berbagai modus kejahatan baru muncul seiring berkembangnya teknologi, mengingat tindakan carding, hacking, penipuan, terorisme, perjudian, dan penyebaran informasi destruktif telah menjadi bagian dari aktifitas pelaku kejahatan yang memanfaatkan kecanggihan teknologi.

Perkembangan teknologi informasi yang sangat pesat telah mempengaruhi seluruh aspek kehidupan termasuk aspek hukum yang berlaku. Kemajuan teknologi informasi tersebut antara lain ditandai dengan maraknya penggunaan media elektronik mulai dari penggunaan handphone hingga komputer yang semakin canggih. Penggunaan media elektronik yang menyangkut teknik untuk mengumpulkan, menyiapkan, menyimpan, memproses mengumumkan, menganalisa dan atau menyebarkan informasi merupakan hal yang sudah lazim dilakukan seseorang di zaman modern ini.

Kemajuan dibidang ilmu pengetahuan dan teknologi telekomunikasi dan informatika juga turut mendukung perluasan ruang gerak transaksi barang dan/atau jasa hingga melintasi batasbatas wilayah suatu negara. Teknologi informasi dan media elektronika dinilai sebagi simbol pelopor, yang akan mengintegrasikan seluruh sistem dunia,baik dalam aspek sosial budaya, ekonomi dan keuangan. Dari sistem-sistem kecil lokal dan nasional, proses globalisasi bergerak cepat, bahkan terlalu cepat menuju suatu sistem global. ${ }^{2}$

Internet berkembang demikian pesat sebagai kultur masyarakat modern, dikatakan sebagai kultur karena melalui internet berbagai aktifitas masyarakat cyber seperti berpikir, berkreasi, dan bertindak dapat diekspresikan didalamnya, kapanpun dan dimanapun. Kehadirannya telah membentuk dunia tersendiri yang dikenal dengan dunia maya (cyberspace) atau dunia semu yaitu sebuah dunia komunikasi berbasis komputer yang menawarkan realitas yang baru berbentuk virtual (tidak langsung dan tidak nyata). ${ }^{3}$

\footnotetext{
${ }^{1}$ https://id.wikipedia.org/wiki/Globalisasi

${ }^{2}$ Didik J Rachbini, Mitos dan Implikasi Globalisasi: Catatan Untuk Bidang Ekonomi dan Keuangan, Pengantar edisi Indonesia dalam Hirst, Paul dan Grahame Thompson, Globalisasi adalah Mitos, Yayasan Obor, Jakarta, 2001, hlm. 2.

${ }^{3}$ Agus Rahardjo, Cybercrime Pemahaman dan Upaya Pencegahan Kejahatan Berteknologi, Citra Aditya Bakti, Bandung, 2002, hlm. 20.
} 
Barda Nawawi Arief mengemukakan cybercrime merupakan salah satu bentuk atau dimensi baru dari kejahatan masa kini yang mendapat perhatian masyarakat luas di dunia internasional, juga merupakan salah satu sisi gelap dari kemajuan teknologi yang mempunyai dampak negatif yang sangat luas bagi seluruh kehidupan modern saat ini. ${ }^{4}$

Kemajuan teknologi menyebabkan kemudahan seseorang untuk dapat mengakses apa saja yang dibutuhkan baik mengenai informasi, transaksi, dan banyak hal lagi lainnya Pemanfaatan teknologi informasi telah banyak mengubah perilaku manusia. Teknologi internet mempunyai pengaruh yang sangat besar terhadap perekonomian dunia.

Internet membawa perekonomian dunia memasuki babak baru yang lebih populer dengan istilah digital economics atau ekonomi digital. Aktivas di dalam internet dapat menjangkau seluruh belahan bumi dengan melampui batas-batas negara. Sesuatu yang dalam dunia nyata jauh dari hadapan, dalam dunia maya dapat dihadirkan seolah-olah dunia itu dekat. Sebagai suatu catatan awal, seseorang dapat memahami bahwa penjual dan pembeli adalah konsumen dari penyelenggaraan suatu sistem elektronik yang telah dikembangkan oleh suatu pihak tertentu (developer) atau diselenggarakan oleh suatu pihak tertentu (provider). Jadi sebagai suatu kajian awal, maka sepatutnya tanggung jawab dan si pengembang dan/atau si penyelenggara sistem elektronik tersebut adalah bersifat mutlak (strict liability), yakni sepanjang sistem yang ada telah dapat diyakini berjalan sebagaimana semestinya, maka risiko baru dapat dikatakan beralih secara fair kepada para penggunanya. ${ }^{5}$

Selain mempunyai dampak positif yang besar, pemanfaatan internet juga mempunyai dampak negatifnya bagi kehidupan masyarakat, salah satunya adalah timbulnya kejahatan. Dampak negatif dapat timbul apabila terjadi kesalahan yang ditimbulkan oleh peralatan komputer yang akan mengakibatkan kerugian besar bagi pemakai (user) atau pihak-pihak yang berkepentingan. kesalahan yang di sengaja mengarah kepada penyalahgunaan computer. ${ }^{6}$

Tidak dapat dipungkiri bahwa kemajuan tekonologi dan pengetahuan bisa membuat kemajuan mengenai kejahatan juga berkembang. Pelaku kejahatan apapun tidak mengenal tempat atau dengan cara apapun selama bisa dijadikan tempat melakukan kejahatan. Di dalam dunia Internet, potensi pelaku kejahatan melakukan kejahatan sangatlah besar dan sangat sulit untuk ditangkap karena antara orang yang ada didalam dunia maya ini sebagian besar fiktif

\footnotetext{
${ }^{4}$ Barda Nawawi Arief, Tindak Pidana Mayantara, Perkembangan Kajian Cybercrime di Indonesia, Raja Grafindo Persada, Jakarta, 2006, hlm. 26.

${ }^{5}$ Edmon Makarim, Kompilasi Hukum Telematika, PT Raja Grafindo, Jakarta, 2003, Hlm 310

${ }^{6}$ Andi Hamzah, Aspek - Aspek Pidana di Bidang Komputer, (Jakarta : Sinar Grafika, 1990), hlm $23-24$.
} 
atau identitas orang per orang tidak nyata. Kejahatan yang terjadi di dalam Internet dikenal dengan istilah Cyber Crime (kejahatan dalam dunia maya).

Kejahatan tersebut dilakukan dengan menggunakan komputer sebagai sarana perbuatannya, salah satu bentuk kejahatan tersebut adalah kejahatan penipuan dengan menggunakan transaksi elektronik. ${ }^{7}$ Berbagai modus penipuan melalui media online pun terus bermunculan dan pelaku semakin rapi dalam memuluskan aksinya dalam tindak penipuan, hal ini di terlihat dari banyaknya website-website jual beli palsu yang dibuat secara sedemikian rupa dan menawarkan berbagai produk dengan harga dibawah harga normal, dengan maksud menarik minat korban untuk membeli, serta ada juga penipuan dengan cara mengorbankan rekening orang lain menjadi tempat hasil tindak pidana penipuan yang bermoduskan pelaku telah mentransfer ke rekening penjual tersebut lebih dari harga yang di sepakati dengan berbagai macam alasan dan meminta kelebihannya di kembalikan ke rekeningnya, namun kenyataannya uang tersebut adalah hasil penipuan pelaku terhadap korban di tempat lain yang mana pelaku berpura-pura menjual suatu barang tertentu, dan memberi nomor rekening korban sebelumnya.

Permasalahan hukum yang sering kali di hadapi pada tindak pidana penipuan online adalah ketika terkait penyampaian informasi, komunikasi, dan atau transaksi elektronik, yakni pada hal pembuktian dan hal yang terkait dengan perbuatan hukum yang dilaksanakan melalui sistem elektronik. ${ }^{8}$ Pasal penipuan dalam Kitab Undang-Undang Hukum Pidana (selanjutnya disebut KUHP) masih belum dapat mengakomodir hal tersebut, dikarenakan biasanya pelaku penipuan melalui media online ini juga menggunakan sarana email untuk berhubungan dengan korbannya, dalam hal ini apakah email sudah dapat dijadikan suatu alat bukti yang sah dan dapat dipersamakan dengan surat kertas layaknya kejahatan penipuan konvensional di dalam dunia nyata.

\section{Rumusan Masalah}

Berdasarkan uraian tersebut di atas, dapat dikemukakan permasalahan sebagai berikut :

a. Bagaimana bentuk pertanggungjawaban terhadap pelaku tindak pidana penipuan online?

b. Bagaimana konsekuensi yuridis pasal 28 ayat (1) Undang-Undang Informasi dan Transaksi Elektronik terhadap pasal 378 Kitab Undang Undang Hukum Pidana pada tindak pidana penipuan online?

\footnotetext{
${ }^{7}$ Sutan Remy Syahdeni, Kejahatan dan Tindak Pidana Komputer, Pustaka Utama Grafiti, Jakarta, 2006, hlm. 8.

${ }^{8}$ Budi Suhariyanto, Tindak Pidana Teknologi Informasi (Cybercrime), Raja Graffindo Persada, Jakarta, 2012, Hlm 3
} 


\section{B. PEMBAHASAN}

Dalam Pasal 1 ayat (3) UUD 1945, menyatakan bahwa: Negara Indonesia adalah negara hukum. Ketentuan tersebut merupakan landasan bagi arah politik hukum dalam pembangunan hukum nasional negara untuk selalu memberikan pelayanan publik, ${ }^{9}$ sehingga sampai saat ini orang bertumpu pada kata segenap bangsa sebagai asas tentang persatuan seluruh bangsa Indonesia. ${ }^{10}$ Disamping itu, kata melindungi mengandung asas perlindungan hukum pada segenap bangsa Indonesia, tanpa kecuali. ${ }^{11}$ Artinya negara turut campur dan bertanggung jawab ${ }^{12}$ dalam upaya mengangkat harkat dan martabat manusia sebagai perwujudan perlindungan hukum. ${ }^{13}$ Pasal ini dapat dikorelasikan dengan pasal-pasal yang mengatur tentang kejahatan penipuan dengan menggunakan transaksi elektronik.

Menurut teori atau paham negara hukum (rechtstaat), negara harus menjamin persamaan setiap warga negara termasuk kemerdekaan menggunakan hak asasinya. Atas dasar itu, negara hukum tidak boleh bertindak sewenang-wenang terhadap warga negaranya dan kekuasaannya harus dibatasi,${ }^{14}$ demikian pula warga negara dibatasi dalam penggunaan hak asasinya dengan hukum sebagai sarananya. ${ }^{15}$ Oleh karena itu, dalam suatu negara hukum kedudukan dan hubungan warga negara dengan negara adalah dalam suasana keseimbangan, sama-sama mempunyai hak yang dilindungi oleh hukum dan samasama dibatasi oleh hukum. ${ }^{16}$

Prinsip-prinsip perlindungan hukum di Indonesia, landasannya adalah Pancasila sebagai ideologi dan falsafah negara. Konsepsi perlindungan hukum bagi rakyat di barat bersumber pada konsep-konsep Rechstaat dan Rule Of The Law. Menggunakan konsepsi barat sebagai kerangka berpikir, dengan landasan Pancasila pada Pancasila. Prinsip perlindungan hukum di Indonesia

\footnotetext{
${ }^{9}$ Ni'matul Huda, Negara Hukum, Demokrasi \& Judicial Review, UII Press, Yogyakarta, 2005, hlm. 8. Lihat Hotma P. Sibuea, Asas Negara Hukum, Peraturan Kebijakan \& Asas-asas Umum Pemerintahan yang Baik, Erlangga, Jakarta, 2010, hlm. 37.

${ }^{10}$ Az. Nasution, Hukum Perlindungan Konsumen (Suatu Pengantar), Diadit Media, Jakarta, 2002, hlm. 31.

11 Ibid

${ }^{12}$ Wagiati Soetedjo, Hukum Pidana Anak, Refika Aditama, Bandung, 2008, hlm. 68.

13 M. Arief Amarullah, Politik Hukum Pidana dalam Perlindungan Korban Kejahatan Ekonomi di Bidang Perbankan, Banyumedia, Malang, 2007, hlm. 2.

${ }^{14}$ Satjipto Rahardjo, Membedah Hukum Progresif, Kompas, Jakarta, 2007, hlm. 240. Lihat A. Mukhtie Fadjar, Tipe Negara Hukum, Banyumedia, Malang, 2005, hlm. 84.

${ }^{15}$ Padmo Wahjono, Indonesia Negara Berdasarkan atas Hukum, Ghalia Indonesia, Jakarta, 1986, hlm. 160.

${ }^{16}$ Konsekuensi, bahwa Indonesia negara berdasarkan hukum (rechtsstaat) tidak berdasarkan atas kekuasaan belaka (machtstaat) dan pemerintahan berdasarkan sistem konstitusi (hukum dasar) bukan absolutisme (kekuasaan yang tidak terbatas) dengan prinsip dasar yang wajib dijunjung tinggi oleh setiap warga negara adalah supremasi hukum, kesetaraan di hadapan hukum, dan penegakan hukum dengan cara-cara yang tidak bertentangan dengan hukum. Lihat Ujang Charda S., "Reaktualisasi Supremasi Hukum dalam Merekonstruksi Lembaga Peradilan Menuju Indonesia Baru”, Jurnal Jurista Insentif'06, Vol. 1 No. 1, Kopertis Wilayah IV Jabar - Banten, Bandung, 2006, hlm. 48-49.
} 
adalah prinsip pengakuan dan perlindungan terhadap harkat dan martabat manusia yang bersumber pada Pancasila. Prinsip perlindungan hukum terhadap tindak pemerintah bertumpu dan bersumber dari konsep tentang pengakuan dan perlindungan terhadap hak-hak asasi manusia karena menurut sejarahnya di Barat, lahirnya konsep-konsep tentang pengakuan dan perlindungan terhadap hak-hak asasi manusia diarahkan kepada pembatasan-pembatasan dan peletakkan kewajiban masyarakat dan pemerintah. ${ }^{17}$

\section{Pertanggungjawaban Pidana Pelaku Tindak Pidana Penipuan Online}

Syarat dalam pembebanan pertanggungjawaban pidana pada pelaku tindak pidana penipuan online adalah terpenuhinya segala unsur tindak pidana dan tujuan dari perbuatan tersebut dapat dibuktikan bahwa memang sengaja dilakukan dengan keadaan sadar akan dicelanya perbuatan tersebut oleh undang-undang. Tindak pidana penipuan menurut Pasal 378 KUHP adalah;

"Barangsiapa dengan maksud untuk menguntungkan diri sendiri atau orang lain secara melawan hukum, dengan memakai nama palsu ataupun rangkaian kebohongan, menggerakan orang lain untuk menyerahkan barang sesuatu kepadanya atau supaya memberi hutang maupun menghapuskan piutang." 18

Tindak pidana penipuan dalam bentuk pokok yang diatur dalam Pasal 378 Kitab UndangUndang Hukum Pidana (KUHP) terdiri dari unsur-unsur sebagai berikut: ${ }^{19}$

- Unsur obyektif :

1) Perbuatan menggerakkan.

2) Yang digerakkan adalah orang (naturlijk person).

3) Tujuan perbuatannya adalah menyerahkan benda, member dan menghapuskan piutang.

- Unsur subyektif

1) Maksud dari perbuatan tersebut adalah untuk menguntungkan diri sendiri dan atau orang lain.

2) Dengan melawan hukum

Meskipun unsur-unsur dalam pasal 378 KUHP tersebut terpenuhi seluruhnya, tetapi terdapat unsur dari tindak pidana penipuan online yang tidak terpenuhi dalam pengaturan pasal 378 KUHP, yaitu :

a.Tidak terpenuhinya unsur media utama yang digunakan dalam melakukan tindak pidana penipuan online yaitu media elektronik yang belum dikenal dalam KUHP maupun KUHAP.

b. Cara-cara penipuan yang berbeda antara penipuan konvensional dengan penipuan online.

\footnotetext{
${ }^{17}$ Philipus M. Hadjon, Perlindungan Hukum Bagi Rakyat Indonesia, Bina Ilmu, Surabaya, 1987, hlm. 38.

${ }^{18}$ Kitab Undang - undang Hukum Pidana, Bab XXV, pasal 378.

${ }^{19}$ PAF Lamintang, Delik-Delik Khusus, PT.Citra Aditya Bakti, Bandung, 1997, hlm 142
} 
c.Terdapat keterbatasan dalam KUHP yaitu tidak dapat membebankan pertanggungjawaban pidana pada subyek hukum yang berbentuk badan hukum (korporasi) yang melakukan tindak pidana penipuan online.

Dengan demikian penipu dalam pasal tersebut pekerjaannya adalah: ${ }^{20}$

1) Membujuk orang supaya memberikannbarang, membuat utang atau menghapuskan utang;

2) Maksud pembujukan itu ialah hendak menguntungkan diri sendiri atau orang lain dengan melawan hukum;

3) Membujuknya itu dengan memakai: nama palsu atau keadaan palsu atau akal cerdik (tipu mislihat) atau karangan perkataan bohong.

Kemudian tindak pidana penipuan akibat transaksi online ini mengakibatkan kerugian konsumen di media internet maka tindak pidana penipuan pada pasal 378 KUHP dihubungkan (juncto) dengan pasal 28 ayat 1 Undang-Undang No. 11 Tahun 2008 tentang Informasi dan Transaksi Elektronik yang berbunyi:

"Setiap Orang dengan sengaja dan tanpa hak menyebarkan berita bohong dan menyesatkan yang mengakibatkan kerugian konsumen dalam transaksi elektronik."21

Berikut adalah unsur-unsur yang terdapat pasal 28 ayat (1) Undang-undang No.11 Tahun 2008, yaitu :

Unsur obyektif :

1) Perbuatan menyebarkan

2) Yang disebarkan adalah berita bohong dan menyesatkan

3) Dari perbuatan tersebut timbul akibat konstitutifnya yaitu kerugian konsumen dalam transaksi elektronik

Unsur subyektif :

1) Unsur kesalahan yaitu dengan sengaja melakukan perbuatan menyebarkan berita bohong dan menyesatkan yang mengakibatkan kerugian konsumen dalam transaksi elektronik

2) Melawan hukum tanpa hak

Terdapat beberapa frasa yang dapat memiliki multitafsir serta beberapa unsur yang kurang tepat tercantum dalam pasal tersebut seperti tidak jelasnya kepada siapa keuntungan melakukan tindakan menyebarkan berita bohong dan menyesatkan yang merugikan konsumen dalam transaksi elektronik, adanya frasa tanpa hak yang dapat ditafsirkan adanya pihak yang memiliki hak untuk menyebarkan berita bohong dan menyesatkan.

\footnotetext{
${ }^{20}$ R. Soesilo, Kitab Undang-Undang Hukum Pidana(KUHP), (Bandung: Politeia, 1996), hlm.261.

${ }^{21}$ Indonesia, Undang-Undang no 11 tahun 2008 tentang informasi dan transaksi elektronik, pasal 28 ayat 1.
} 
Dengan sanksi pidana pada Pasal 45 ayat 2 UU No 11 Tahun 2008 tentang ITE yang berbunyi:

"Setiap Orang yang memenuhi unsur sebagaimana dimaksud dalam pasal 28 ayat 1 dan 2 dipidana dengan pidana penjara paling lama 6 (enam tahun dan/atau denda paling banyak Rp. 1.000.000.000,00 ( satu miliar rupiah )."22

Melihat perbandingan pengaturan antara pasal tersebut, maka untuk pembebanan pertanggungjawaban pidana tentu saja akan memiliki perbedaan yaitu perbedaan sanksi pidana pada pasal 378 KUHP dan pasal 28 ayat (1), bila pada pasal 378 KUHP hanya terdapat sanksi pidana penjara selama 4 tahun, sedangkan dalam pasal 28 ayat (1) UU ITE tidak secara langsung mencantumkan sanksi pidana melainkan tertera pada pasal 45 ayat (2) UU ITE yaitu sanksi pidana penjara paling lama 6 tahun dan juga terdapat sanksi denda sebesar satu milyar rupiah, tidak dikenalnya subyek hukum badan hukum (korporasi) dalam KUHP yang akan berakibat lolosnya subyek hukum tersebut untuk dimintai pertanggungjawaban pidana, beda halnya dalam UU ITE telah mengenal subyek hukum yang berbentuk badan hukum (korporasi).

Pengaturan mengenai penyebaran berita bohong dan menyesatkan ini sangat diperlukan untuk melindungi konsumen yang melakukan transaksi komersial secara elektronik. Perdagangan secara elektronik dapat dilaksanakan dengan mudah dan cepat. Idealnya, transaksi harus didasarkan pada kepercayaan para pihak yang bertransaksi (mutual trust). Kepercayaan ini diasumsikan dapat diperoleh apabila para pihak yang bertransaksi mengenal satu sama yang didasarkan pada pengalaman transaksi terdahulu atau hasil diskusi secara langsung sebelum transaksi dilakukan. Dari segi hukum, para pihak perlu membuat kontrak untuk melindungi kepentingan mereka dan melindungi mereka dari kerugian-kerugian yang mungkin muncul dikemudian hari. Kontrak berisi hak dan kewajiban masing-masing pihak yang bertransaksi. Selain itu, kontrak ini juga biasanya diakhiri dengan pilihan hukum dan/atau yuridiksi hukum yang dapat diterima oleh para pihak apabila terjadi sengketa atau perselisihan. Hal ini menjadi ketentuan yang sangat penting apabila transaksi tersebut dilakukan oleh para pihak yang berbeda kewarganegaraan.

Setelah melihat perbedaan pengaturan dan pertanggungjawaban pidana antara pasal 378 KUHP dan pasal 28 ayat (1) UU ITE, terdapat beberapa poin penting, yaitu :

1. KUHP memiliki unsur menguntungkan diri sendiri dan orang lain,

${ }^{22}$ Ibid pasal 45 ayat 2 
Sedangkan dalam undang-undang ITE tidak jelas kepada siapa penipuan tersebut di tujukan, yang terpenting adalah adanya kerugian konsumen dalam transaksi elektronik tidak peduli pada siapa yang di untungkan.

2. KUHP belum mengenal subyek hukum badan hukum (korporasi),

Sedangkan ITE telah mengenal subyek hukum badan hukum (korporasi).

3. KUHP tidak mengenal transaksi elektronik ataupun media elektronik yang

Dalam hal ini adalah obyek penting sarana pelaku untuk melakukan tindak pidana penipuan online, pada undang-undang ITE telah dikenal adanya informasi, transaksi dan media elektronik.

4. Adanya perbedaan akibat dan tujuan dari perbuatan yang di cantumkan pada

Dua pasal dalam dua undang-undang tersebut. Pasal 378 KUHP tujuan nya menguntungkan diri sendiri dan atau orang lain, akibat yang ditmbulkan adalah adanya penyerahan benda dari orang yang berhasil di pengaruhi untuk di gerakkan sesuai keinginan pelaku, adanya pemberian dan penghapusan hutang piutang. Sedangkan dalam pasal 28 ayat (1) UU ITE tidak tercantumnya unsur tujuan untuk keuntungan siapakah pelaku melakukan tindak pidana tersebut, pasal ini hanya mencantumkan akibat terjadinya tindak pidana tersebut yaitu kerugian konsumen dalam transaksi elektronik.

5. Adanya cara yang jelas dan terperinci untuk melakukan tindak pidana

Penipuan dalam KUHP yaitu dengan nama palsu, martabat/ kedudukan palsu, serta rangkain kebohongan dan tipu muslihat, sedangkan dalam UU ITE tidak terdapat cara melainkan hanya mencantumkan perbuatan yaitu menyebarkan berita bohong dan menyesatkan.

6. Adanya perbedaan sanksi dalam KUHP dan UU ITE, perbedaan tersebut terlihat oleh adanya sanksi denda dalam UU ITE.

\section{Konsekuensi Yuridis Penggunaan Pasal 28 Ayat (1) UU ITE Terhadap Pasal 378 KUHP Pada Tindak Pidana Penipuan Online}

KUHP sebagai dasar hukum pemidanaan utama di Indonesia telah mengatur tentang aturan yang melarang tindak pidana penipuan yang tertera pada pasal 378 KUHP. Unsur penipuan dalam pasal 378 KUHP masih bersifat penipuan secara konvensional, yaitu penipuan yang umumnya terjadi dan di peruntukan pada semua hal yang ada dalam dunia nyata. Penggunaan pasal 378 KUHP kurang tepat apabila digunakan untuk menjerat tindak pidana penipuan online yang terdapat pada dunia maya (cyberspace) dengan menggunakan media elektronik sebagai sarana untuk melakukan tindak pidananya, dikarenakan adanya 
keterbatasan dalam alat bukti yang secara limitiatif dibatasi oleh KUHAP dan permasalahan yurisdiksi dalam menangani perkara cybercrime.

Pasal 28 ayat (1) UU ITE tidak secara langsung mengatur mengenai tindak pidana penipuan konvensional maupun tindak pidana penipuan online, tetapi unsur-unsur di dalam pasal 28 ayat (1) UU ITE identik dan memiliki beberapa kesamaan pada tindak pidana penipuan konvensional yang diatur dalam pasal 378 KUHP dan memiliki karakteristik khusus yaitu telah diakuinya bukti, media elektronik, dan adanya perluasan yurisdiksi dalam UU ITE.

Melihat hal tersebut penulis berpendapat bahwa terjadi beberapa konflik hukum yaitu konflik aturan dimana terdapat dua pasal dalam dua Undang-Undang mengatur hal yang identik yaitu tindak pidana penipuan antara pasal 28 ayat (1) UU ITE dengan pasal 378 KUHP serta terdapat kekaburan makna norma pada unsur-unsur yang ada dalam kedua pasal tersebut. Konflik hukum dapat menyebabkan disfungsi hukum yang artinya hukum tidak dapat berfungsi memberikan pedoman berprilaku kepada masyarakat, pengendalian sosial, dan penyelesaian sengketa untuk menciptakan keadilan dan kepastian hukum di masyarakat. ${ }^{23}$

Disfungsi hukum tersebut dapat diatasi dengan beberapa cara, salah satunya adalah menerapkan asas atau doktrin hukum lex specialis derogate legi generalis. Pasal 28 ayat (1) UU ITE memiliki karakteristik unsur yang lebih spesifik dibandingankan pasal 378 KUHP dalam konteks pemidanaan pada tindak pidana penipuan online, dapat dikatakan bahwa pasal 28 ayat (1) UU ITE merupakan lex specialis derogat legi generalis dari pasal 378 KUHP. Selain karena memiliki karakteristik unsur yang lebih spesifik dalam konteks pemidanaan pada tindak pidana penipuan online, pasal 28 ayat (1) UU ITE telah memenuhi beberapa prinsip dalam asas lex specialis derogate legi generalis yaitu $:^{24}$

a) Ketentuan-ketentuan yang didapati dalam aturan hukum umum tetap berlaku, kecuali yang diatur khusus dalam aturan hukum khusus tersebut.

b) Ketentuan-ketentuan lex specialis harus sederajat dengan ketentuaketentuan lex generalis (Undang-undang dengan Undang-undang).

c) Ketentuan-ketentuan lex specialis harus berada dalam lingkungan hukum (rezim) yang sama dengan lex generalis.

\footnotetext{
${ }^{23}$ A.A. Oka Mahendra, Harmonisasi Peraturan Perundang-undangan, KemenkumHam.go.id, http://ditjenpp.kemenkumham.go.id/htn-dan-puu/421-harmonisasi-peraturan-perundangundangan.html, diakses 24 Juli 2014

${ }^{24}$ Ibid
} 
Barda Nawawi Arief ${ }^{25}$ menyatakan bahwa membicarakan masalah yurisdiksi Cyber pada hakikatnya berkaitan dengan masalah kekuasaan atau kewenangan, yaitu siapa yang berkuasa atau berwenang mengatur dunia internet. Mengenai masalah ini, David R. Jhonson dan David G. Post (sebagaimana yang dikutip oleh barda nawawi Arief) mengemukakan 4 (empat) model yang salang bersaing, yaitu:

a. Pelaksanaan kontrol yang dilakukan oleh badan-badan pengadilan yang saat ini ada (the exixting judicial forums);

b. Penguasa nasional melakukan kesepakatan internasional mengenai the governance of cyber space;

c. Pembentukan suatu organisasi internasional baru (A New International Organization) yang secara khusus menangani masalah-masalah didunia internet; dan

d. Pemerintahan atau pengaturan sendiri (Self Governance) oleh para pengguna internet.

\section{PENUTUP}

1) Kesimpulan

Berdasarkan pembahasan makalah seagaimana telah diuraikan dalam bab pembahasan tersebut di atas, maka ditarik kesimpulan sebagai berikut :

Bentuk pertanggungjawaban pidana pelaku tindak pidana penipuan online hanya dapat dijatuhi menggunakan pasal 28 ayat (1) juncto pasal 45 ayat (2) Undang-Undang Nomor 8 Tahun 2011 Tentang Informasi Dan Transaksi Elektronik. Pasal 378 KUHP tentang tindak pidana penipuan tidak dapat digunakan untuk membebani pelaku tindak pidana penipuan online untuk mempertanggungjawabkan perbuatannya, dikarenakan terdapat beberapa kendala dalam membebani sanksi pidana pada pelaku tindak pidana seperti kendala dalam pembuktian dimana alat bukti yang dibatasi oleh KUHAP, dalam pasal 378 KUHP hanya mengenal subyek hukum orang (naturlijk persoon), dan terdapat kesulitan menentukan yurisdiksi untuk menggunakan hukum mana, siapa yang berhak untuk menghukum pelaku karena penipuan online termasuk kedalam kejahatan lintas negara dan cybercrime dimana salah satu karekteristiknya tidak dapat di batasi oleh batas-batas wilayah kedaulatan suatu negara.

a.Dengan adanya kekurangan pada KUHP tersebut maka, pasal 28 ayat (1) juncto pasal 45 ayat (2) undang-undang nomor 8 tahun 2011 tentang Informasi Dan Transaksi Elektronik meskipun tidak secara khusus mengatur ketentuan mengenai tindak pidana

${ }^{25}$ H. Sutarwan, CIBER CRIME : Modus Operandi Dan Penanggulangannya, (Jogjakarta: Laksbang Pressindo, 2007), hal: 123 
penipuan meskipun dalam konteks berbeda tetapi tetap dapat di gunakan untuk membebani pelaku untuk mempertanggungjawabkan perbuatannya dalam hal tindak pidana penipuan online, pada aktivitas transaksi elektronik atau dapat dikatakan jualbeli online mengingat konteks sebenarnya dari adanya undang-undang ITE adalah sebagai perlindungan konsumen.

Konsekuensi yuridis dari penggunaan pasal 28 ayat (1) undang-undang ITE terhadap pasal 378 KUHP pada tindak pidana penipuan online adalah kedua pasal dalam dua undangundang tersebut saling mengesampingkan dan mengecualikan. Pasal 28 ayat (1) undangundang ITE hanya dapat di gunakan pada tindak pidana penipuan online yang berkarakteristik pada aktivitas jual beli online saja, sedangkan pada pasal 378 KUHP hanya dapat di gunakan untuk menjerat pelaku tindak pidana penipuan konvensional, dengan kata lain pasal 28 ayat (1) UU ITE merupakan lex specialis dari pasal 378 KUHP yang merupakan lex generalis dari tindak pidana penipuan, meskipun keduanya juga memiliki kekaburan makna norma dalam unsur-unsur tindak pidananya. Melihat unsur dan modus penipuan online yang semakin canggih dan mengikuti perkembangan zaman,

penggunaan pasal 28 ayat (1) undang-undang ITE di rasa sangat tepat untuk langsung di dakwakan terhadap pelaku agar tidak akan timbul kekhawatiran lolosnya pelaku dari pembebanan pemidanaan pada tindakannya.

2) Saran

Adapun saran dari penulis mengenai pokok permasalahan yang timbul dalam tulisan ini adalah sebagai berikut:

Rekomendasi serta saran yang dapat di berikan oleh peneliti dalam penelitan yang dilakukan pada kedua pasal dalam dua undang-undangtersebut adalah di harapkan adanya reformasi dan perombakan dalam Kitab Undang-Undang Hukum Pidana (KUHP) di sebabkan banyaknya kejahatan dengan modus-modus baru yang di khawatirkan KUHP tidak dapat mengakomodirnya mengingat kejahatan berkembang mengikuti perkembangan zaman dan masyarakat. Hal tersebut diperuntukkan untuk tetap menjaga 3 fungsi hukum yaitu kepastian, kemanfaatan dan keadilan. Selanjutnya perlu penyempurnaan UU ITE dimana masih terdapat kekurangan yang salah satunya tidak di atur secara khususnya tentang tindak pidana penipuan online dan masih terbatas konteksnya pada perlindungan konsumen dalam aktivitas jual beli bukan terhadap segala

aktivitas penipuan online. Peneliti juga berharap penelitian ini juga dapat bermanfaat bagi para akademisi yang lain apabila akan meneliti bahan hukum yang sama sebagai acuan atau bahan penelitiannya dapat menggunakan penelitian ini sebagai masukan dan sumber referensinya. 


\section{DAFTAR PUSTAKA}

Amarullah, M. Arief, 2007, Politik Hukum Pidana dalam Perlindungan Korban Kejahatan Ekonomi di Bidang Perbankan, Banyumedia, Malang.

Charda S, Ujang, 2006, Reaktualisasi Supremasi Hukum dalam Merekonstruksi Lembaga Peradilan Menuju Indonesia Baru, Jurnal Jurista Insentif'06, Vol. 1 No. 1, Kopertis Wilayah IV Jabar - Banten, Bandung.

Fadjar, A.Mukhtie, 2005, Tipe Negara Hukum, Banyumedia, Malang.

Hamzah, Andi, 1990, Aspek - Aspek Pidana di Bidang Komputer, Jakarta, Sinar Grafika .

Huda, Ni'matul, 2005, Negara Hukum, Demokrasi \& Judicial Review, UII Press, Yogyakarta.

J Rachbini, Didik, 2001, Mitos dan Implikasi Globalisasi: Catatan Untuk Bidang Ekonomi dan Keuangan, Pengantar edisi Indonesia dalam Hirst, Paul dan Grahame Thompson, Globalisasi adalah Mitos, Yayasan Obor, Jakarta.

Lamintang, PAF, 1987, Delik-Delik Khusus, PT.Citra Aditya Bakti, Bandung.

Makarim, Edmon, 2003, Kompilasi Hukum Telematika, PT Raja Grafindo, Jakarta.

Mahendra, Oka, Harmonisasi Peraturan Perundang-undangan, KemenkumHam.go.id, http://ditjenpp.kemenkumham.go.id/htn-dan-puu/421-harmonisasi-peraturan perundangundangan.html, diakses 24 Juli 2014

M. Hadjon, Philipus, 1987, Perlindungan Hukum Bagi Rakyat Indonesia, Bina Ilmu, Surabaya.

Nasution, Az., 2002, Hukum Perlindungan Konsumen (Suatu Pengantar), Diadit Media, Jakarta.

Nawawi, Arief Barda, 2006, Tindak Pidana Mayantara, Perkembangan Kajian Cybercrime di Indonesia, Raja Grafindo Persada, Jakarta.

P. Sibuea, Hotma, 2010, Asas Negara Hukum, Peraturan Kebijakan \& Asas-asas Umum Pemerintahan yang Baik, Erlangga, Jakarta.

Rahardjo, Agus, 2002, Cybercrime Pemahaman dan Upaya Pencegahan Kejahatan Berteknologi, Citra Aditya Bakti, Bandung.

Rahardjo, Satjipto, 2007, Membedah Hukum Progresif, Kompas, Jakarta.

Remy Syahdeni, Sutan, 2006, Kejahatan dan Tindak Pidana Komputer, Pustaka Utama Grafiti, Jakarta. 
Soesilo, R., 1996, Kitab Undang-Undang Hukum Pidana(KUHP), Bandung, Politeia.

Soetedjo, Wagiati, 2008, Hukum Pidana Anak, Refika Aditama, Bandung.

Suhariyanto, Budi, 2012, Tindak Pidana Teknologi Informasi (Cybercrime), Raja Graffindo Persada, Jakarta.

Sutarwan, H, 2007, CIBER CRIME : Modus Operandi Dan Penanggulangannya, (Jogjakarta: Laksbang Pressindo.

Wahjono, Padmo, 1986, Indonesia Negara Berdasarkan atas Hukum, Ghalia Indonesia, Jakarta.

\section{PERUNDANG-UNDANGAN}

KUHP

Undang-Undang Nomor 8 Tahun 2011 Tentang Informasi Dan Transaksi Elektronik 